\title{
An in vitro and in vivo comparative study of directly compressed solid dispersions and freeze dried sildenafil citrate sublingual tablets for management of pulmonary arterial hypertension
}

REHAM ZAYED ${ }^{1}$

AMANY O. KAMEL 2,*

MARWA SHUKR

ABD EL-HAMID EL-SHAMY²

1 Department of Pharmaceutics

National Organization for Drug

Control and Research, Cairo, Egypt

2 Department of Pharmaceutics and Industrial Pharmacy, Faculty of Pharmacy Ain Shams University, Cairo, Egypt

Accepted May 30, 2012

\begin{abstract}
Sildenafilcitrate (SILD) orodispersable sublingual tablets (ODSTs) have been developed using two comparative techniques for improving their oral disintegration, dissolution and bioavailability in order to manage acute attacks of pulmonary arterial hypertension (PAH). The techniques employed were direct compression of SILD-poloxamer 188 solid dispersions (SDs) and freeze drying using various excipients. The physicochemical and solid-state properties, as well as the dissolution behavior of the tablets were evaluated. Moreover, SILD bioavailability in human volunteers from the prepared ODSTs was compared to that of the conventional oral tablet. Incorporation of SD of poloxamer188 in sublingual tablets together with Pharmaburst using the direct compression technique enhanced the extent and dissolution rate of SILD with $100 \%$ of drug being dissolved after 7 minutes. However, the lyophilization process was superior in enhancing dissolution and $100 \%$ of SILD was dissolved after only one minute. Moreover, the in vivo study showed that the $A U C_{0-12}$ of lyophilized tablets was significantly higher than that of directly compressed tablets, with bioavailability values of 159.81 and $140.85 \%$, respectively, compared to the commercial oral product.
\end{abstract}

Keywords: sildinafil, orodispersable sublingual tablets, pulmonary arterial hypertension, poloxamer 188, solid dispersions, direct compression, freeze drying

Pulmonary arterial hypertension (PAH) is a life-threatening disease. It is characterized by elevations in the pulmonary arterial pressure and pulmonary vascular resistance, leading to right ventricular failure and premature death (1). Treatments of PAH include medications, oxygen, and lung transplant. The main medications for pulmonary

\footnotetext{
* Correspondence; e-mail: amany.kamel@yahoo.com
} 
hypertension include: endothelin receptor antagonists, prostacyclin analogs and phosphodiesterase type 5 inhibitors (PDE5Is).

Sildenafil citrate (SILD), a selective inhibitor of cGMP specific phosphodiesterase type 5 (PDE5), was approved by the FDA for the treatment of PAH in 2005. It improves cardiovascular diseases and is useful for patients with congestive heart failure as well as secondary pulmonary hypertension. It relaxes the arterial wall, and hence decreases the pulmonary arterial resistance and pressure. This improves symptoms of right-sided heart failure by reducing the workload of the right ventricle of the heart. Since PDE5 is primarily distributed within the arterial wall smooth muscle of the lungs and penis, SILD acts selectively in both of these areas without inducing vasodilation in other areas of the body, which is considered to be an advantage of SILD(2-3). SILD decreases myocardial apoptosis, fibrosis, and hypertrophy by activating protein kinase $\mathrm{G}$, inhibiting Rho kinase, and increasing Blc-2 (4-5). Moreover, SILD was shown to prevent hypoxic pulmonary vasoconstriction without affecting systemic hemodynamics in healthy adults breathing $11 \%$ oxygen (6).

SILD is currently available on the market in the form of oral tablets and intravenous injections. Although the peroral route is consideredby patients and clinicians to be the most convenient route for drug delivery, the oral bioavailability of SILD is only $40 \%$ and a high-fat meal delays its absorption (7-8). Parenteral administration overcomes this drawback and provides excellent bioavailability; however, it involves poor patient compliance. These limitations have stimulated the development of alternative administration routes such as trans-buccal mucosal routes, whichare now among the most popular routes for systemic drug delivery. Sublingual mucosa is characterized by high blood supply and hence rapid absorption and acceptable bioavailability of many drugs is achieved. Buccalmucosa is substantially less permeable than the sublingual area and hence does not provide rapid absorption and enhanced bioavailability observed with sublingual administration (9).

In this study, orodispersable sublingual tablets (ODSTs) containing SILD,which is absorbed through the sublingual mucosa and enters directly into the systemic circulation avoiding the first pass metabolism, were prepared in an attempt to enhance its bioavailability and produce rapid onset of action for the treatment of PAHvia a comfortable delivery system. Two techniques for improving oral disintegration, dissolution and bioavailability were comparatively studied. The first technique employed was direct compression of solid dispersions (SDs) of SILD using poloxamer as a carrier and the second technique was freeze drying using various excipients. Physicochemical and solid-state properties, as well as the dissolution behavior of the tablets were evaluated. Moreover, SILD bioavailability in human volunteers from the prepared ODSTs was compared to that of the conventional tablet available in the market.

\section{EXPERIMENTAL}

\section{Materials}

Sildenafil citrate was kindly supplied by Eva Pharm, Egypt. Polyethylene glycol (PEG4000, PEG6000, PEG8000), Poloxamer188, Xanthum gum, xylitol and mannitol were purchased from Sigma Aldrich. PVPK30 was purchased from HIMEDIALaboratories Pvt. 
R. Zayed et al.: An in vitro and in vivo comparative study of directly compressed solid dispersions and freeze dried sildenafil citrate sublingual tablets for management of pulmonary arterial hypertension, Acta Pharm. 62 (2012) 411-432.

Ltd. Maltodextrin DE 29 was purchased from RoquettePharma. Spray dried mannitol and Avicel PH 101 were kindly supplied by EPICO, Egypt. AC-DI-SOL, magnesium stearate, sodium starch glycolate, glycine and gelatin were purchased from EL NASR Pharmaceutical Chemicals, Egypt. Pharmaburst ${ }^{\circledR} 500$ was kindly supplied by SPIPharma.

Preparation of sildenafil-polyethylene glycol and sildenafil-poloxamer188 solid dispersion (SD) sublingual tablets

Preparation of physical mixtures

Physical mixtures of SILD and PEG 4000, PEG 6000, PEG 8000 and Poloxamer 188 were prepared in ratios of 1:1, 1:2 and 1:3 by mixing calculated amounts of the drug and polymers in a mortar. The resulting mixtures were sieved using sieves of mesh size $0.2-0.25 \mathrm{~mm}$. The physical mixtures were stored in a desiccator at room temperature until evaluation.

Preparation of SD

PEG 4000, PEG 6000, PEG 8000 and Poloxamer 188 were mixed with SILD in ratios of 1:1, 1:2 and 1:3. The mixtures were fused under constant stirring on a thermostatically controlled hot plate (Hot Plate \& Stirrer, The Netherlands). After melting, the mixtures were allowed to cool and were then stored in tightly closed containers in desiccators over calcium chloride (0\% relative humidity) at room temperature until dryness. SDs were then ground using a mortar and pestle and the particle size was controlled by sieving through sieves of mesh size $0.2-0.25 \mathrm{~mm}$.

Solubility studies

Excess amounts of SILD, SILD-PEG and SILD-Poloxamer 188 physical mixtures as well as SDs were suspended in distilled water in tightly closed screw-cap vials, equilibrated in a shaking water bath at room temperature for 48 hours, then filtered using a $0.45-\mu \mathrm{m}$ Millipore filter and assayed spectrophotometrically (Shimadzu 2450, Japan) at predetermined $\lambda_{\max }$. Three determinations were carried out to calculate the saturated solubility of SILD.

\section{Dissolution studies}

In vitro dissolution studies were carried out in $500 \mathrm{~mL}$ of distilled waterin order to maintain sink conditions (10). Briefly, an amount of $20 \mathrm{mg}$ of SILD free drug and an equivalent amount of drug loaded SDs were transferred to a USP Dissolution Tester, Apparatus II (Hanson SR8 dissolution test station,USA) rotating at $100 \mathrm{rpm}$ and maintained at $37 \pm 0.5^{\circ} \mathrm{C}$. At predetermined time intervals $(5,10,15,30,45$ and $60 \mathrm{~min})$, an aliquot of dissolution medium was withdrawn and analyzed spectrophotometerically for drug content. Withdrawn samples were replaced by freshly distilled water. All the determinations were carried out in triplicate.

Bitterness evaluation by a taste panel

This test was done to evaluate the effectiveness of SDs in masking the bitter taste of SILD. The test was carried out on six healthy human volunteers. The protocol of the 
study was reviewed and approved by the institutional review board of the Genuine Research Center, Cairo, Egypt. Before the test, all volunteers received a detailed explanation of the purpose of the study and gave their written consent. The volunteers were informed abouta numerical scale gradingthe bitterness before the test. Pure SILD and SDs of an amount equivalent to $20 \mathrm{mg}$ SILD were held in the volunteers' mouth for $10 \mathrm{~s}$, and then they were asked to report their results after $10 \mathrm{~s} \mathrm{(11).}$

\section{Differential Scanning Calorimetery (DSC)}

Thermal studies were performed to examine the effect of the polymers used as dispersing carriers on SILD using differential scanning calorimetry (DSC 60 Shimadzu, Japan). Pure SILD, polymer, and SDs were sealed in aluminum pans and heated over a temperature range of $20-300{ }^{\circ} \mathrm{C}$ at a linear heating rate of $10{ }^{\circ} \mathrm{C} \mathrm{min}-1$ in a nitrogen atmosphere.

\section{X-ray powder diffraction analysis (XRPD)}

X-ray powder diffraction (XRPD) patterns of the SILD, polymer and the selected SD were recorded on an X-ray diffractometer (X-Pert Graphics \&Idenify, Philips Analytical, The Netherlands) with an area detector operating at a voltage of $40 \mathrm{kV}$ and a current of $30 \mathrm{~mA}$ using CuKa radiation. The scanning rate was 1.2 degree $\mathrm{min}^{-1}$ and the scanning scope of $2 \Theta$ was from 5 to $40^{\circ}$ at room temperature.

Fourier transform infrared spectroscopy (FTIR)

SILD, polymer and the selected SD were examined by FTIR (ThermoScientificNicolet 6700 , USA). Samples of 2-3 mg were ground with $100 \mathrm{mg}$ of dry potassium bromide powder and compressed into a disc with a hydrostatic press. The scanning range was $400-4000 \mathrm{~cm}^{-1}$.

Preparation of tablets by direct compression

SILD SD tablets were prepared by the direct compression technique. Each tablet was composed of SD containing an amount equivalent to $20 \mathrm{mg}$ of SILD, magnesium stearate as lubricant, xylitol and peppermint as sweetening and flavoring agents, respectively. Two types of superdisintegrants were used, either sodium starch glycolate (SSG) together with PVP K30, Avicel PH 101 as binder and spray dried mannitol as diluent (S1-S4) or Pharmaburst ${ }^{\circledR} 500$ (S5-S8). All ingredients were used at different concentrations, as shown in Table I. Before compression, the previously sieved SDs and excipients were mixed in a glass mortar, followed by tumbling for $15 \mathrm{~min}$ in a Turbulamixer, then the lubricant was added and mixing was continued for further $5 \mathrm{~min}$. The powder mix was compressed using a single tablet machine with aflat-faced punch of 7-mm diameter (MiniPress II, Karnavaty, India).

Preparation of SILD lyophilized sublingual tablets

Two groups of lyophilized tablets were prepared using two different matrix formers; the first was maltodextrin which also acts as diluent and collapse protectant, together with Xantham gum (X.gum) asbinder and viscosity enhancer, xylitol as sweetener and PEG 8000; these formulae were coded as F1-F3. The second matrix former was gelatin formulated together with mannitol as diluent, glycine as collapse protectant and PEG 
R. Zayed et al.: An in vitro and in vivo comparative study of directly compressed solid dispersions and freeze dried sildenafil citrate sublingual tablets for management of pulmonary arterial hypertension, Acta Pharm. 62 (2012) 411-432.

Table I. Composition of SILD SD sublingual tablets

\begin{tabular}{lcccccccc}
\hline Ingredient $(\mathrm{mg})$ & S8 & S7 & S6 & S5 & S4 & S3 & S2 & S1 \\
\hline SD1 & - & 40 & - & 40 & - & 40 & - & 40 \\
lparSD10 & 40 & - & 40 & - & 40 & & 40 & - \\
Pharmaburst & 78 & 78 & 58 & 58 & - & - & - & - \\
SSG & - & - & - & - & 25 & 25 & 10 & 10 \\
Avicel PH 101 & - & - & - & - & 10 & 10 & 10 & 10 \\
PVP K30 & - & - & - & - & 3 & 3 & 3 & 3 \\
Peppermint & 1 & 1 & 1 & 1 & 1 & 1 & 1 & 1 \\
Xylitol & 0.5 & 0.5 & 0.5 & 0.5 & 0.5 & 0.5 & 0.5 & 0.5 \\
Spray dried Mannitol & - & - & - & - & 20 & 20 & 35 & 35 \\
Mg-stearate & 0.5 & 0.5 & 0.5 & 0.5 & 0.5 & 0.5 & 0.5 & 0.5 \\
Total tablet mass & 120 & 120 & 100 & 100 & 100 & 100 & 100 & 100 \\
\hline
\end{tabular}

8000; these formulae were coded as F4-F9. All ingredients were used at different concentrations, as shown in Table II. Briefly, an accurately weighed amount of SILD powder was dispersed in an aqueous solution of the matrix former and other excipients under stirring with a magnetic stirrer to result in a dose of $20 \mathrm{mg}$ of SILD per 0.4 milliliter. An amount of 0.4 milliliter of each prepared suspension was then poured into the pockets of a PVC blister pack, resulting in tablets of $20 \mathrm{mg}$ each. Tablet blister packs were then kept in a freezer at $-28{ }^{\circ} \mathrm{C}$ for 24 hours. Frozen tablets were placed in a lyophilizer for 24 hours using a Novalyphe-NL 500 Freeze Dryer. The condenser temperature was $-45^{\circ} \mathrm{C}$ and the pressure was $7 \times 10^{-2}$ mbar. Lyophilized tablets were then kept in tightly closed containers in desiccators at room temperature.

Evaluation of prepared tablets

Prepared SILD tablets were subjected to the quality control tests, namely,mass uniformity, drug content, hardness, friability, and in vitro disintegration tests.

Table II. Composition of SILD lyophilized sublingual tablets

\begin{tabular}{lccccccccc}
\hline Ingredient $(\mathrm{g} / 40 \mathrm{~mL})$ & $\mathrm{F} 1$ & $\mathrm{~F} 2$ & $\mathrm{~F} 3$ & $\mathrm{~F} 4$ & F5 & F6 & F7 & F8 & F9 \\
\hline SILD & 2 & 2 & 2 & 2 & 2 & 2 & 2 & 2 & 2 \\
Maltodextrin & 3 & 4 & 4.5 & - & - & - & - & - & - \\
X.gum & 1 & 1 & 1 & - & - & - & - & - & - \\
Gelatin & - & - & - & 1 & 1 & 2 & 2 & 3 & 3 \\
PEG8000 & 2 & 2 & 2 & - & 2 & - & 2 & - & 2 \\
Mannitol & - & - & - & 4 & 4 & 4 & 4 & 4 & 4 \\
Xylitol & 2 & 1 & 0.5 & - & - & - & - & - & - \\
Glycine & - & - & - & 1 & 1 & 1 & 1 & 1 & 1 \\
\hline
\end{tabular}




\section{Moisture content}

A Karl Fischer titrator was used for assessment of residual moisture in the tablets processed by lyophilization. Each tablet was crushed, placed in the titration vessel containing dried methanol (Karl Fischer grade) and titrated with Hydranal Composite 5 reagent (Riedel-de-Haen, Seelze, Germany) after stirring for 3 minutes. The test results presented are the mean \pm SD.

\section{Wetting time and water absorption ratio}

Ten milliliters of distilled water containing the water-soluble dye eosin were added into a Petri dish of $10 \mathrm{~cm}$ diameter. The tablets were placed in the center of the Petri dish and the time required for water to reach the upper surface of the tablets was recorded as the wetting time. The results are the mean value \pm SD.

For the water absorption ratio $(R)$, tablets were weighed before wetting $\left(W_{\mathrm{b}}\right)$ and after wetting $\left(W_{\mathrm{a}}\right)$ and the ratio was calculated according to the following equation (12):

$$
R=100\left(W_{\mathrm{a}}-W_{\mathrm{b}}\right) / W_{\mathrm{b}}
$$

\section{In vivo oral disintegration time}

Oral disintegration time was tested on six healthy volunteers. The protocol of the study was reviewed and approved by the institutional review board of the Genuine Research Center, Cairo, Egypt. Before the test, all volunteers received a detailed explanation of the purpose of the study and gave their written consent. Each of the six volunteers was asked to rinse his mouth with distilled water and was then given a coded tablet and instructed to place the tablet under the tongue. The time required for complete disintegration of the tablet was recorded. The volunteers were allowed to spit out the content of the oral cavity after tablet disintegration and rinse their mouth with distilled water (13). The test results are presented as the mean value \pm S.D.

\section{In vitro dissolution studies}

In vitro dissolution studies of sublingual and lyophilized tablets containing $20 \mathrm{mg}$ of SILD together with the conventional market product Revatio ${ }^{\circledR} 20$ mg oral tablets (Pfizer, USA) were carried out as previously done for the dissolution of SDs. At predetermined time intervals $(1,2,3,5,7,10,15,20$, and $30 \mathrm{~min})$, an aliquot of the dissolution medium was withdrawn and analyzed spectrophotometrically for drug content. Withdrawn samples were replaced by freshly distilled water. All determinations were carried out in triplicate.

Dissolution profiles of the prepared tablets were compared with the commercial product using the similarity factor $(f 2)$ defined by the following equation (14):

$$
f_{2}=50 \log \left\{\left[1+\frac{1}{n} \sum_{t=1}^{n}\left(R_{t}-T_{t}\right)^{2}\right]^{-0.5} \times 100\right\}
$$

where $n$ is the number of sampling time points, $R_{\mathrm{t}}$ and $T_{\mathrm{t}}$ are the mean percent dissolved of the reference (commercial product) and the test (prepared sublingual tablets), respec- 
tively, up to each time point t. $f 2$ represents a logarithmic transformation of the sum-squared error of differences between the reference and the test products over all time points. In order to consider similar dissolution profiles, $f 2$ values should be higher than 50 (50-100).

\section{Statistical analysis}

All statistical analyses were made using ANOVA, followed by Fisher's PLSD (pairwise least significant difference) for multiple comparisons at $p \leq 0.05$ using the StatView statistical software program.

\section{Pharmacokinetic study on healthy volunteers}

\section{Subject selection}

Six healthy volunteers aged between 20 and 40 years were chosen. None of the volunteers had any history of drug or alcohol abuse, nor did they have any acute or chronic gastrointestinal, cardiac, vascular, hepatic or renal diseases. The protocol of the study was reviewed and approved by the institutional review board of the Genuine Research Center, Cairo, Egypt. The research was carried out in accordance with the international clinical research guidelines, enunciated in the Declaration of Helsinki,adopted in Helsinki in 1964 and amended in Seoul, South Korea, October 2008 (15). The purpose of the study was fully explained and the volunteers gave their written consent. The informed consent forms were carefully read before signing. All questions were discussed in detail with the clinical staff. Special emphasis was placed on the adherence of subjects to the study protocol and on the possible adverse events. The subjects were instructed to take no drugs for one week prior to and during the course of the study.

\section{Study design}

Randomized, single dose, three-way crossover open-label study was performed using three SILD formulations,viz., the prepared F4 and S7 sublingual tablets and the conventional market product Revatio ${ }^{\circledR} 20 \mathrm{mg}$ oral tablets (Pfizer, USA). Following an overnight fast of at least 10 hours in all phases, subjects swallowed the conventional oral tablet (Revatio ${ }^{\circledR} 20$ mg tablets) with a cup of water, and the sublingual formulations were properly put under the tongue and were not swallowed. No additional water or fluids were alloweduntil 2 hours after the dose. A standard meal was provided at approximately 4 hours after drug administration. Meal plans were identical in the three periods and were served approximately at the same time. Subjects were housed after dosing until the 12-hour blood draw. Seven days were allowed between the three doses, as washout periods.

\section{Sample collection}

Venous blood samples were collected in glass tubes before administration of the dosage form, and at $0.25,0.50,0.75,1.00,1.50,2.00,2.50,3.00,4.00,6.00,8.00$, and 12.00 hours after drug administration. All samples were collected and plasma was immediately separated from blood cells by centrifugation at $3000 \mathrm{rpm}$ for $10 \mathrm{~min}$ and stored frozen at $-20^{\circ} \mathrm{C}$ until analysis. 


\section{Determination of SILD in human plasma}

A sensitive, selective and accurate LC-MS/MS method was developed and validated before the study for determination of SILD in human plasma. The method was validated following international guidelines (16). Torsemide internal standard (IS) stock solution was prepared by dissolving $10 \mathrm{mg}$ in methanol and was serially diluted with the

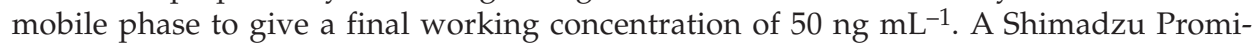
nence (Shimadzu, Japan) series LC system equipped with a degasser (DGU-20A3), solvent delivery unit (LC-20AB) and an auto-sampler (SIL-20 AC) was used to inject $20 \mu \mathrm{L}$ aliquots of processed samples on a Luna C (Phenomenex, USA) $(50 \times 4.6) \mathrm{mm}$, having a $5-\mu \mathrm{m}$ particle size. All analyses were carried out at room temperature. The isocratic mobile phase $(\mathrm{pH} 4.5)$ consisted of acetonitrile and (0.02 M) ammonium acetate buffer $(70 \%$, $30 \%, V / V)$ and $0.1 \%$ formic acid delivered at a fiow rate of $1.0 \mathrm{~mL} \mathrm{~min}^{-1}$ into the mass spectrometer's electrospray ionization chamber. Quantitation was achieved by MS/ MS detection in the positive ion mode for both SILD and IS, using a MDS Sciex (Foster City, CA, USA) API-3200 mass spectrometer, equipped with a turbo ionspray interface at 300 ${ }^{\circ} \mathrm{C}$. The ion spray voltage was set at $5500 \mathrm{~V}$. Common parameters, viz., nebulizer gas, curtain gas, auxiliary gas and collision gas were set at 30,22, 20 and 5 psi, respectively. Compound parameters, viz., declustering potential (DP), collision energy (CE), entrance potential (EP) and collision exit potential (CXP) were $76 \mathrm{~V}, 63 \mathrm{~V}, 10 \mathrm{~V}, 4 \mathrm{~V}$ for SILD and $31 \mathrm{~V}, 23 \mathrm{~V}, 6 \mathrm{~V}, 4 \mathrm{~V}$ for Torsemide (IS), respectively. Ion detection was performed in the multiple reaction monitoring (MRM) mode, monitoring the transition of the $\mathrm{m} / \mathrm{z} 475.2$ precursor ion to the 58.2 for SILD and 348.9 precursor ion to the $m / z 263.9$ for IS. Quadrupoles Q1 and Q3 were set at unit resolution. Analytical data were processed using Analyst Software (Version 1.4.2).

\section{Sample preparation}

Frozen human plasma samples were thawed at ambient temperature. Human plasma samples $(1.0 \mathrm{~mL})$ were placed in 5 - $\mathrm{mL}$ glass tubes, and $1 \mathrm{~mL}$ acetonitrile containing IS was added to each and vortexed for $1 \mathrm{~min}$. The upper layer was then transferred to the autosampler vial and $20 \mu \mathrm{L}$ was injected into the system.

\section{Pharmacokinetic and statistical analyses}

Plasma concentration-time data of SILD was analyzed for each subject by non-compartmental pharmacokinetic models using Kinetica ${ }^{\circledR}$ Software (version 4.4.1). Peak plasma concentrations $\left(C_{\max }\right)$ and the time of their occurrence $\left(T_{\max }\right)$ were directly obtained from the concentration-time data. The area under the plasma concentration-time curve $\left(A U C_{0-12}\right)$ from time zero to the last measured concentration was calculated according to the linear trapezoidal rule. The terminal elimination rate constant $(\lambda z)$ was estimated by linear regression of the terminal portion of the ln (concentration)-time curve, and the elimination half-life was calculated. Relative bioavailability of SILD sublingual tablets compared to the commercial product was calculated according to the following equation: 
R. Zayed et al.: An in vitro and in vivo comparative study of directly compressed solid dispersions and freeze dried sildenafil citrate sublingual tablets for management of pulmonary arterial hypertension, Acta Pharm. 62 (2012) 411-432.

$$
\text { Relative bioavailability }(\%)=\frac{A U C_{0-12}(\text { Sublingual tablets })}{A U C_{0-12}(\text { Commercial oral tablets })}
$$

Analysis of variance was used to assess the effect of the formulation on pharmacokinetic parameters. Differences between two related parameters were considered statistically significant for $p$-value equal to or less than 0.05 .

\section{RESULTS AND DISCUSSION}

\section{Characterization of SDs}

Solubility and dissolution

There was a significant increase in the solubilityof prepared physical mixtures compared to the plain drug (results not shown). Moreover, Table III shows that SDs significantly increased the solubility of SILD up to 1.65 fold, except for PEG 6000 which showed a non-significant increase in solubility $(p<0.05)$. It is worthy to note that the solubility of SILD from SDs was significantly higher than from their physical mixture counterparts, so physical mixtures were excluded from further testing.

SDs prepared using poloxamer 188, PEG 4000 and PEG 8000 enhanced SILD dissolution compared to the plain drug and physical mixtures; the percentage of SILD dis-

Table III. Solubility, percentage dissolved after 5 minutes and taste score of the different prepared SDs

\begin{tabular}{cccccc}
\hline Code & Carrier & $\begin{array}{c}\text { Drug/polymer } \\
\text { ratio }(w / w)\end{array}$ & $\begin{array}{c}\text { Solubility } \pm \text { SD } \\
\mathrm{mg} \mathrm{mL}^{-1}\end{array}$ & $\begin{array}{c}\text { Percentage dissolved } \\
\text { after } 5 \text { minutes }(\%)\end{array}$ & $\begin{array}{c}\text { Taste score } \\
\text { after } 10 \mathrm{~s}\end{array}$ \\
\hline SILD & - & - & $3.4 \pm 0.3$ & $81 \pm 3.5$ & $3+$ \\
SD1 & & $1: 1$ & $5.2 \pm 0.01$ & $93.6 \pm 0.6$ & 1.5 \\
SD2 & Poloxomer & $1: 2$ & $5.62 \pm 0.02$ & $96 \pm 1$ & 1 \\
SD3 & 188 & $1: 3$ & $5.2 \pm 0.4$ & $96.5 \pm 1.2$ & 1 \\
SD4 & & $1: 1$ & $4.92 \pm 0.1$ & $89 \pm 0.4$ & 2 \\
SD5 & PEG 4000 & $1: 2$ & $4.95 \pm 0.05$ & $88 \pm 0.9$ & 1 \\
SD6 & & $1: 3$ & $5.3 \pm 0.2$ & $94.5 \pm 1.5$ & 0.5 \\
SD7 & & $1: 1$ & $4.45 \pm 0.08$ & $65 \pm 0.6$ & 2 \\
SD8 & PEG 6000 & $1: 2$ & $4.4 \pm 0.07$ & $82 \pm 0.7$ & 1 \\
SD9 & & $1: 3$ & $3.7 \pm 0.14$ & $83.5 \pm 0.34$ & 1 \\
SD10 & & $1: 1$ & $5.24 \pm 0.35$ & $89 \pm 0.4$ & 2 \\
SD11 & PEG 8000 & $1: 2$ & $5.47 \pm 0.28$ & $87 \pm 0.9$ & 1 \\
SD12 & & $1: 3$ & $5 \pm 0.07$ & $93 \pm 1.1$ & 0.5 \\
\hline
\end{tabular}

0 - tasteless, 0,5 - very slight, 1 - slight to moderate, 2 - moderate, 2.5 - moderate to strong, 3 - strong, $3+-$ very strong 
solved after 5 min. was more than 93, 88 and $87 \%$ from SDs prepared using poloxamer, PEG 4000 and PEG 8000, respectively. However, the percentage of SILD dissolved after 5 min. from SDs prepared using PEG 6000 was in the range of 65 to $83.5 \%$.

The efficiency of SDs in enhancing the solubility and dissolution of SILD could be due to the formation of a high energy metastable state of SDs (17) and a reduction in particle size in addition to the presence of carrier, which prevented aggregation of fine drug particles, thus providing a larger surface area for dissolution (18).

The superiority of poloxamer in enhancing the solubility and dissolution of SILD is due to its wetting property and surface activity, which resulted in a decrease in the interfacial tension between the medium and the drug and, hence, higher SD dissolution. Moreover, the presence of a larger number of H-bond forming groups resulted in the development of a strong force that inhibited agglomeration and recrystallization of the drug, leading to optimal dispersion of the system (19-20).

\section{Bitterness evaluation}

Bitterness evaluation revealed reduction in the bitterness score of the plain drug from very strong to moderate, slight and very slight when incorporated in SDs (Table III). This is due to the efficiency of SDs in masking the bitter taste (21).

The above results indicate that SD1 and SD10 prepared using a small polymer amount (drug to polymer ratio 1:1) showed high solubility (with no significant difference from other SDs of high solubility) and high dissolution rate and extent along with good masking of bitterness and were hence chosen for further studies.

\section{Differential scanning calorimetry (DSC)}

The DSC thermograms (Fig. 1) of SILD, poloxamer and PEG8000 gave sharp endothermic peaks at 198,52 and $63^{\circ} \mathrm{C}$, respectively.SD1 thermogram showed two endother-

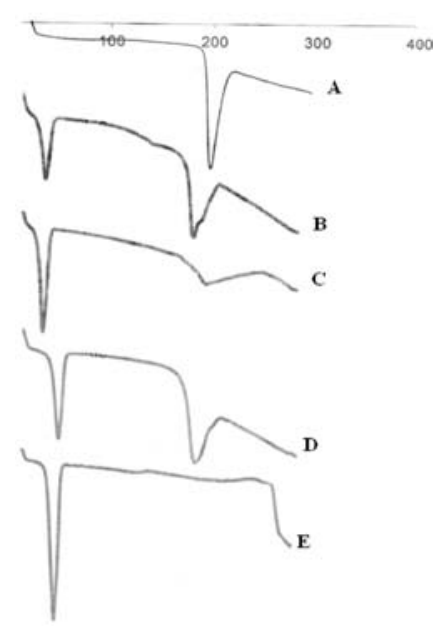

Fig. 1. DSC thermograms of A) SILD, B) SD1, C) poloxamer 188, D) SD10, E) PEG8000. 
mic transitions. One was very close to poloxamer melting temperature at $55{ }^{\circ} \mathrm{C}$, and the other corresponded to the drug at $200{ }^{\circ} \mathrm{C} . \mathrm{SD} 10$ thermogram showed two endothermic transitions. One was very close to PEG8000 melting temperature at $65{ }^{\circ} \mathrm{C}$, and the other corresponded to the drug at $204{ }^{\circ} \mathrm{C}$. The peaks corresponding to the drug in SDs were shortened and broadened, indicating an interaction that may suggest formation of a hydrogen bond between the lone pair of electrons of the drug nitrogen atom and the $\mathrm{OH}$ group of the polymer.

\section{$X$-ray powder diffraction analysis $(X R P D)$}

The XRPD pattern (Fig. 2) shows sharp peaks for SILD at $2^{\circ}$ theta $4.3^{\circ}, 7.3^{\circ}, 8.07^{\circ}$, $10.27^{\circ}, 14.4^{\circ}$ and $19.8^{\circ}$ indicating crystallinity of the drug. PEG8000 shows sharp peaks at $19.1^{\circ}, 22.97^{\circ}, 23.22^{\circ}$ and $23.5^{\circ}$ whereas those for poloxamer are shown at $19.2^{\circ}, 23.35^{\circ}$ and $23.48^{\circ}$. SD1 and SD10 show a decrease in peak number and intensity in comparison with pure SILD, where in case of SD10 peak intensity at $8.08^{\circ}$ decreased from 4840 to 1124 , at $10.2^{\circ}$ from 1467 to 680 , at $14.3^{\circ}$ from 3385 to 557 and at $19.8^{\circ}$ from 865 to 496 , while small peaks at $4.3^{\circ}, 14.67^{\circ}$ and $15.08^{\circ}$ had disappeared. Peaks of PEG 8000 at 19.1 decreased from 1391 to 1056 , at 22.9 from 1377 to 953 and at 23.5 from 1237 to 734 . SD1 alsoshowed a decrease in major peak intensity and number, at 8.08 from 4840 to 1024 , at 14.3 from 3386 to 480 and at 19.8 from 865 to 482 , peaks at 4.3 and at 15.08 had disappeared. The decrease in peak number and the decrease in peak intensity of SILD indicate a reduction in its crystallinity in the formulated solid dispersions.Moreover,it might have dispersed as a microcrystalline form that enhances its solubility and dissolution.

\section{Fourier transform infrared spectroscopy (FTIR)}

FTIR study (Fig. 3) shows peaks for PEG8000 at 3481, 2887 and $1105 \mathrm{~cm}^{-1}$ and at 3437,2887 and $1147 \mathrm{~cm}^{-1}$ for poloxamer 188,corresponding to the stretching associated

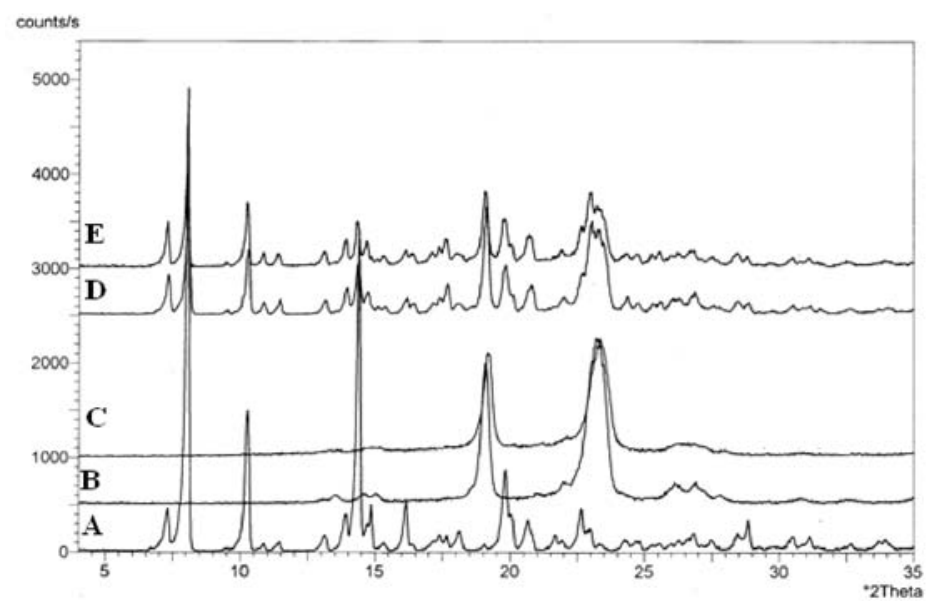

Fig. 2. X-ray diffraction patterns of A) SILD, B) PEG8000, C) poloxamer 188, D) SD10 and E) SD1. 


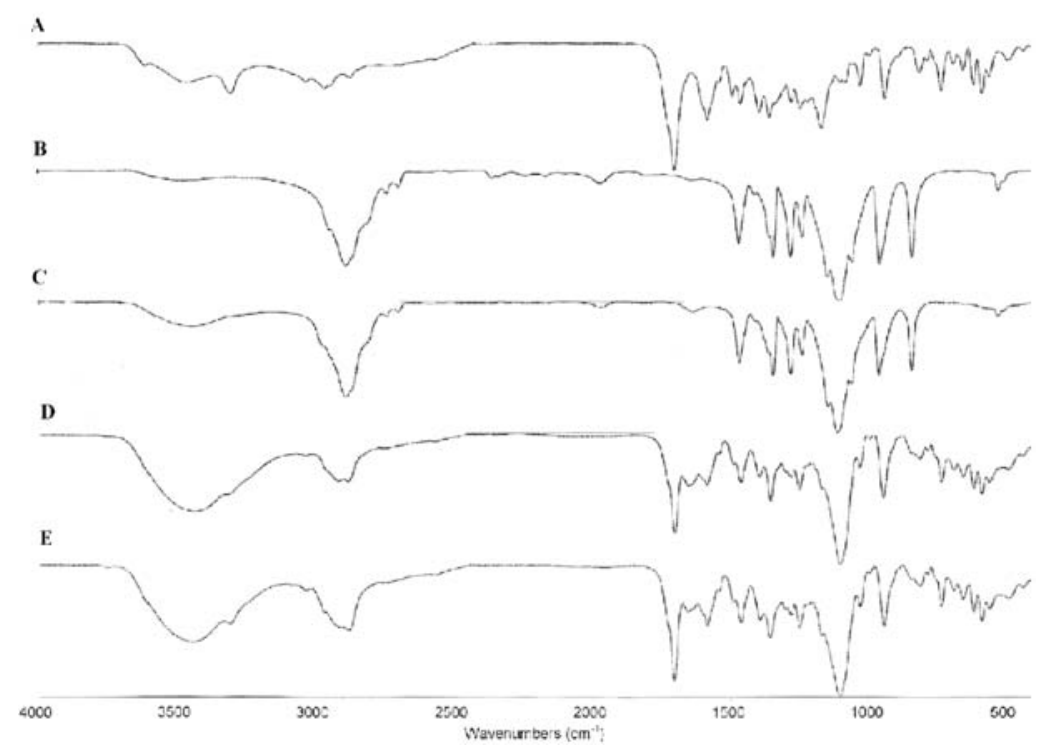

Fig. 3.FTIR spectra of A) SILD, B) PEG8000, C) poloxamer 188, D) SD10 and E) SD1.

with $\mathrm{O}-\mathrm{H}, \mathrm{C}-\mathrm{H}$ and $\mathrm{C}-\mathrm{O}$ bonds, respectively. The drug shows peaks at 1170 and 1359 $\mathrm{cm}^{-1}$ for symmetric and asymmetric SO2, respectively, at 1582 and $1702 \mathrm{~cm}^{-1}$ for symmetric and asymmetric $\mathrm{COOH}$, respectively, at $3301 \mathrm{~cm}^{-1}$ for the $\mathrm{N}-\mathrm{H}$ group, and peaks from 3030 to $2733 \mathrm{~cm}^{-1}$ corresponding to aliphatic C-H. Analysis of the spectra of SDs shows broadening of peaks at $3430 \mathrm{~cm}^{-1}$, suggesting the formation of a hydrogen bond between the lone pair of electrons of the drug nitrogen atom and the $\mathrm{OH}$ group of the polymer (22), which explainsthe enhanced solubility of SD together with the decrease in drug crystallinity.

\section{Evaluation of the prepared tablets}

SILD SD sublingual tablets

As shown in Table IV, SILD SD sublingual tablets showed uniformity in thickness and diameter with average diameter ranging from $6.86 \pm 0.05$ to $6.94 \pm 0.07 \mathrm{~mm}$ and average thickness ranging from $2.04 \pm 0.03$ to $2.35 \pm 0.09 \mathrm{~mm}$, indicating uniform die fill. None of the prepared tablets deviated from the stated limit ( $\pm 5 \%)$ of mass variation, indicating proper mixing of excipients with SD. All the assayed tablets are within the pharmacopoeiallimit $( \pm 15 \%)$ for drug content.Friability of the tested tablets ranged from zero to $0.13 \%$ and their hardness ranged from 35 to $57 \mathrm{~N}$ with an average of $44.7 \mathrm{~N}$, indicating good mechanical strength that can withstand mechanical and physical stress during handling. However, S3 was sticking to the punch and was excluded from the study. 
R. Zayed et al.: An in vitro and in vivo comparative study of directly compressed solid dispersions and freeze dried sildenafil citrate sublingual tablets for management of pulmonary arterial hypertension, Acta Pharm. 62 (2012) 411-432.

Wetting time and water absorption ratio

Table IV shows thatthe formulations containingPharmaburst (S5, S6, S7, S8) gave a short wetting time, ranging from 3.8 to $5.7 \mathrm{~s}$, and higher water absorption ratio, ranging from 32 to $37 \%$. On the other hand, those containing SSG (S1, S2, S4) gave a significantly higher wetting time, ranging from 35 to $87 \mathrm{~s}$, and lower water absorption ratio, ranging from 9 to $18 \%$. It is worthy to note that increasing the SSGconcentration from 10 to $25 \%$ shortened the wetting time from 87 to $35 \mathrm{~s}$ and increased the water absorption ratio.

In vitro disintegration time (DT)

In vitro disintegration time (DT) of formulations prepared using Pharmaburst was significantly lower than that of those prepared using SSG, with values ranging from 88 to $180 \mathrm{~s}$ and from 250 to 300 s, respectively (Table IV).

\section{In vivo oral $D T$}

In vivo oral DT (Table IV) ranged from 75to 180s for Pharmaburst formulations while those of SSG ranged from 180 to $300 \mathrm{~s}$. These results indicate a good correlation between in vitro and in vivo studies and again show that Pharmaburst significantly shortened DT in comparison with SSG.

The short wetting time, increase in absorption ratio together with shorter DT of Pharmaburstformulations may be explained by the fact that Pharmaburst is a coprocessed excipient composed of crospovidone,mannitol, sorbitol and precipitated silicon dioxide. It dissolves quickly with a good mouthfeel. It was developed to provide optimum compaction, friability, rapid disintegration and creamy mouthfeel. Moreover, crospovidone as a superdisintegrantpossesses porous particle morphology that enables rapid absorption of liquids, up to $50 \%$, into the tablet by capillary action and generates rapid volume expansion and hydrostatic pressure that result in tablet disintegration and increased absorption ratio and consequently short wetting time (23).

Table VI. Evaluation of SILD SD sublingual tablets

\begin{tabular}{cccccccccc}
\hline Code & $\begin{array}{c}\text { Diameter } \\
(\mathrm{mm})\end{array}$ & $\begin{array}{c}\text { Thickness } \\
(\mathrm{mm})\end{array}$ & $\begin{array}{c}\text { Drug con- } \\
\text { tent }(\%)\end{array}$ & $\begin{array}{c}\text { Hard- } \\
\text { ness }(\mathrm{N})\end{array}$ & $\begin{array}{c}\text { Friabil- } \\
\text { ity }(\%)\end{array}$ & $\begin{array}{c}\text { Wetting } \\
\text { time }(\mathrm{s})\end{array}$ & $\begin{array}{c}\text { Waterabs } \\
\text { orp-tion } \\
\text { ratio }(\%)\end{array}$ & $\begin{array}{c}\text { In vitro } \\
\text { DT (s) }\end{array}$ & $\begin{array}{c}\text { In vivo oral } \\
\text { DT (s) }\end{array}$ \\
\hline S1 & $6.92 \pm 0.06$ & $2.29 \pm 0.07$ & $98.5 \pm 0.2$ & $35 \pm 0.7$ & zero & $40 \pm 0.15$ & 16 & $300 \pm 0.11$ & $240 \pm 0.2$ \\
S2 & $6.94 \pm 0.07$ & $2.04 \pm 0.03$ & $100 \pm 0.41$ & $36 \pm 0.8$ & zero & $87 \pm 0.3$ & 9 & $250 \pm 0.1$ & $180 \pm 0.5$ \\
S4 & $6.86 \pm 0.05$ & $2.3 \pm 0.10$ & $104 \pm 0.2$ & $44 \pm 0.2$ & 0.7 & $35 \pm 0.21$ & 18 & $300 \pm 0.3$ & $300 \pm 0.1$ \\
S5 & $6.93 \pm 0.03$ & $2.27 \pm 0.03$ & $102 \pm 0.2$ & $45 \pm 0.7$ & zero & $4.8 \pm 0.2$ & 32 & $88 \pm 0.4$ & $75 \pm 0.3$ \\
S6 & $6.92 \pm 0.05$ & $2.20 \pm 0.05$ & $110 \pm 0.1$ & $57 \pm 0.1$ & zero & $4.5 \pm 0.1$ & 37 & $90 \pm 0.17$ & $85 \pm 0.4$ \\
S7 & $6.9 \pm 0.01$ & $2.3 \pm 0.01$ & $105 \pm 0.3$ & $50 \pm 0.5$ & 0.13 & $5.7 \pm 0.1$ & 34 & $90 \pm 0.6$ & $80 \pm 0.33$ \\
S8 & $6.93 \pm 0.02$ & $2.35 \pm 0.09$ & $112 \pm 0.5$ & $46 \pm 0.1$ & 0.08 & $3.8 \pm 0.3$ & 35 & $180 \pm 0.12$ & $180 \pm 0.2$ \\
\hline
\end{tabular}




\section{In vitro dissolution}

Results of theinvitro dissolution study illustrated in Fig. 4 show that not all the prepared SD sublingual tablets prepared by direct compression were superior to the conventional market product. The dissolution profile of S1 and S4 was similar to the commercial product, with $f 2$ values of 51.26 and 52.44, respectively,while the dissolution profile of S2 was significantly lower than the market product with the $f 2$ value of 43.25. However, only S5, S6, S7 and S8 showed significantly higher dissolution profiles compared to the commercial product, with the $f 2$ values of 33.83, 37.89, 27.92 and 33.72, respectively.

Comparing the profiles of the sublingual tablets prepared using direct compression, it was observed that formulations prepared using Pharmaburst (S5, S6, S7 and S8) gave a higher release rate and extent of SILD compared to those prepared using SSG where $100 \%$ of SILD was released from Pharmaburstformulations after 7 min; however, S1, S2 and S4 prepared using SSG released $100 \%$ of the drug after 15, 20 and $15 \mathrm{~min}$., respectively. These findings come in agreement with the results of the wetting time, water absorption ratio and DT.

By further inspection of Fig. 4, it was observed that formulations prepared using poloxamer as a solid carrier (SD1) were superior to those prepared using PEG8000 (SD10), as manifested by higher dissolution of S5 compared to S6, S7 compared to S8, and S1 compared to S2. As previously mentioned, this might be due to the presence of a larger number of H-bond forming groups, which resulted in the development of a strong force that inhibited agglomeration and recrystallization of the drug, leading to optimal dispersion of the system.

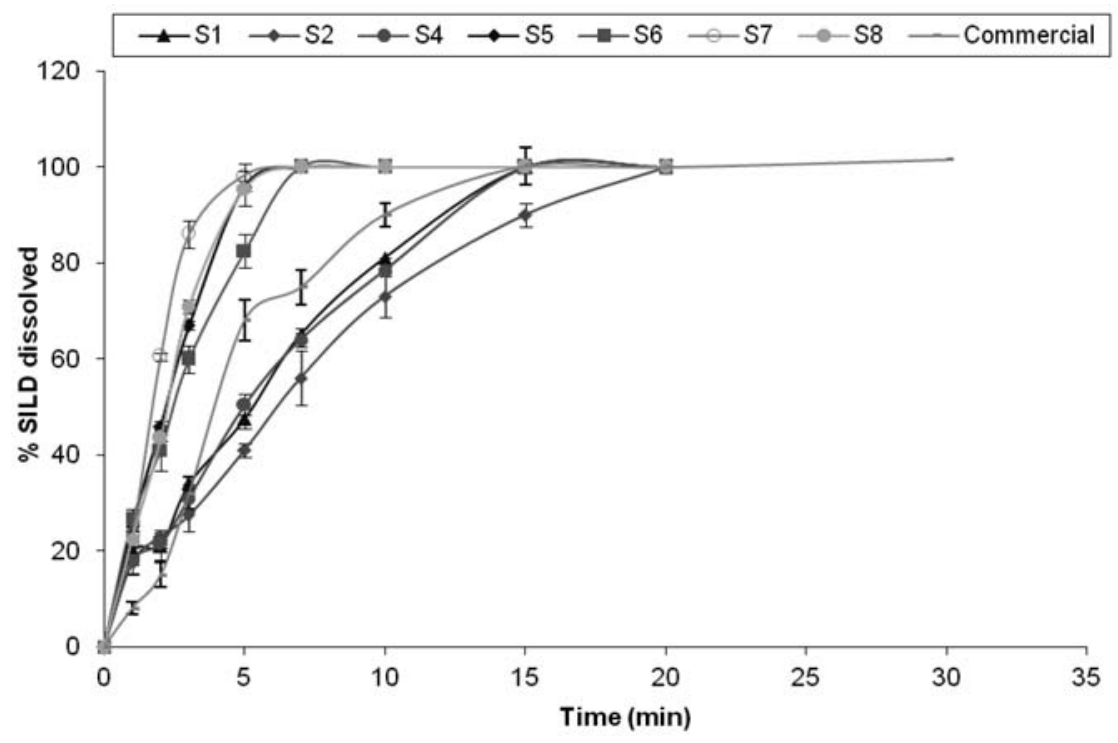

Fig. 4. Dissolution profiles of SILD SD sublingual tablets in $500 \mathrm{~mL}$ distilled water. 
It is worthy to note that incorporation of SD of poloxamer188 in sublingual tablets together with Pharmaburst gave a better extent and release rate than SD of PEG8000, as evidenced by the higher dissolution of S5 and S7 compared to S1, and S6 and S8 compared to S2.

It was also observed that increasing the concentration of Pharmaburst from 58 to 78 $\mathrm{mg}$ and SSG from 10 to $25 \mathrm{mg}$ enhanced dissolution (S5 vs. S7, S6 vs. S8 and S2 vs. S4).

According to the above results, $\mathrm{S} 7$ was proven to be superior compared to other formulations and was hence subjected to further in vivo studies.

\section{Lyophilized sublingual tablets}

Formulations prepared using maltodextrin as a matrix former (F1, F2, and F3) showed low mechanical strength and inelegant appearance and could not withstand manual handling, so these formulations were excluded from further testing. All other formulations were within acceptable pharmacopoeial requirements for both mass variation and drug content uniformity (Table V). Friability of tested tablet formulations was zero \%, except for F5 which was $2.2 \%$ that deviated from the acceptable limit andwas excluded from further testing. This might be due to the low concentration of gelatin, which decreases mechanical strength (24),along with the effect of PEG8000, a low melting point glycol, that caused a decrease of tablet hardness and accordingly an increase in tablet friability (25). The residual moisture content in lyophilized tablets was very small, not exceeding $5 \%$, indicating that lyophilization was efficient in removing water from the tablets. The remaining moisture is required to maintain the integrity of tablets and prevent them from cracking (Table V).

\section{Wetting time and in vitro disintegration time (DT)}

Wetting time increased with increasing gelatin concentration, where F4, F6 and F8 gave wetting times of 9,10 , and $20 \mathrm{~s}$, respectively. Moreover, increasing the gelatin concentration caused an increase in the in vitro disintegration time, with F4 having the shortest disintegration time (Table V). This is due to a decrease in the binding properties of gelatin by decreasing its concentration (26).

Table V. Evaluation of SILD lyophilized sublingual tablets

\begin{tabular}{ccccccccc}
\hline Code & $\begin{array}{c}\text { Theore- } \\
\text { tical mass }\end{array}$ & $\begin{array}{c}\text { Mass } \\
\text { afterlyophili } \\
\text { zation }\end{array}$ & $\begin{array}{c}\text { Drug } \\
\text { content }\end{array}$ & $\begin{array}{c}\text { Friabil- } \\
\text { ity }(\%)\end{array}$ & $\begin{array}{c}\text { Residual } \\
\text { moisture } \\
(\%)\end{array}$ & $\begin{array}{c}\text { Wetting } \\
\text { time }(\mathrm{s})\end{array}$ & $\begin{array}{c}\text { In vitro } \\
\text { DT(s) }\end{array}$ & $\begin{array}{c}\text { In vivo DT } \\
\text { (s) }\end{array}$ \\
\hline F4 & 80 & $76.5 \pm 1.87$ & $100 \pm 0.7$ & zero & $4.46 \pm 0.11$ & $9 \pm 0.4$ & $3 \pm 0.2$ & $10 \pm 0.3$ \\
F6 & 90 & $86 \pm 1.69$ & $96.3 \pm 1.7$ & zero & $4.38 \pm 0.87$ & $10 \pm 0.6$ & $22 \pm 0.35$ & $15 \pm 0.4$ \\
F7 & 110 & $109.4 \pm 1.7$ & $96.8 \pm 3$ & zero & $4.23 \pm 0.5$ & $12 \pm 0.2$ & $26 \pm 0.55$ & $20 \pm 0.7$ \\
F8 & 100 & $95 \pm 3$ & $99.2 \pm 3$ & zero & $2.53 \pm 0.6$ & $20 \pm 0.1$ & $25 \pm 0.9$ & $23 \pm 0.4$ \\
F9 & 120 & $115 \pm 3$ & $103.5 \pm 0.7$ & zero & $3.4 \pm 0.7$ & Long time & $120 \pm 0.3$ & $115 \pm 0.9$ \\
\hline
\end{tabular}




\section{In vivo oral $D T$}

Table $\mathrm{V}$ shows that the in vivo oral DT could be arranged in the following ascending order, F4 $<$ F6 $<$ F7 $<$ F $8<$ F9 where F4 prepared using $1 \%$ gelatin showed the shortest DT of $10 \mathrm{~s}$, while F9 prepared using $3 \%$ gelatin showed the longest DT of $115 \mathrm{~s}$. The increase in DT with an increase in gelatin concentration might be explained by the fact that during the freeze-drying process the aqueous solutions of gelatin are rapidly cooled, leading to the formation of a 3D gel network with water trapped inside, and then the trapped rozen water sublimates, leaving behind only the 3D network. By increasing gelatin concentration, a larger number of crosslinks and inter-chain H-bonds are formed between the gelatin strands (27) and since the mechanism of disintegration is due to the weakening of intermolecular bonds upon penetration of the disintegration medium between the tablet's excipients, increasing gelatin concentration delays DT.

Studying the effect of PEG 8000 as disintegrant on the invivo disintegration time, it was found that PEG 8000 did not decrease DT - the in vivo DT was $20 \mathrm{~s}$ for F7 vs. $15 \mathrm{~s}$ for $\mathrm{F} 6$ and $115 \mathrm{~s}$ for F9 vs. $23 \mathrm{~s}$ for F8. This was due to the increase in the solid concentration of the prepared formulae on adding PEG, which decreased the ability of ice to grow during the freezing step and hence decreased the number of pores left after the sublimation stage, resulting in longer DT (28).

Comparing the in vivo DT of lyophilized tablets with that of SD tablets prepared by direct compression, it was observed that the DT of lyophilized tablets ranged from 10 to $115 \mathrm{~s}$ and that of SD prepared by direct compression ranged from 75 to $240 \mathrm{~s}$, indicating that the lyophilization process is more efficient in formulation of sublingual tablets.

\section{In vitro dissolution study}

The cumulative percent of drug dissolved as a function of time from lyophilized tablets is illustrated in Fig. 5. All the prepared lyophilized sublingual tablets gave significantly higher dissolution than the market product in the first 5 minutes, with the $f 2$ values of 15.2, 16.8, 20.86, 33.65 and 46.2 for F4, F6, F7, F8 and F9, respectively.

The percentage of drug dissolved from lyophilized tablets in $1 \mathrm{~min}$ can be arranged in the descending order as follows F4 > F6 > F7 > F8 > F9 with values of 100, 89, 51, 38 and $24 \%$, respectively. These results indicate that lyophilization enhanced the dissolution of SILD; complete dissolution was achieved from F4 in 1 min and from F6 and F7 within $5 \mathrm{~min}$ and was retarded by $20 \mathrm{~min}$ in cases of F8 and F9. Decrease in the dissolution rate in case of F8 and F9 was due to the high content of gelatin compared to other formulations, which was correlated with both disintegration time and wetting time that were increased by the increase in gelatin concentration.

By inspection of Fig. 5, it was observed that the percentage of SILDdissolved from formulations containing PEG was lower than from their counterparts with no PEG. This might be due to the decrease in PEG solubility due to its high molecular mass.

It is worthy to note that thelyophilization process was superior in enhancing dissolution compared to direct compression; $100 \%$ of SILD was dissolved after only one minute (F4) compared to $7 \mathrm{~min}$ (S7) in direct compression.

Lyophilization is a robust process; it imparts a glassy amorphous porous structure to the bulking agent, thereby enhancing the dissolution characteristics of the formula- 


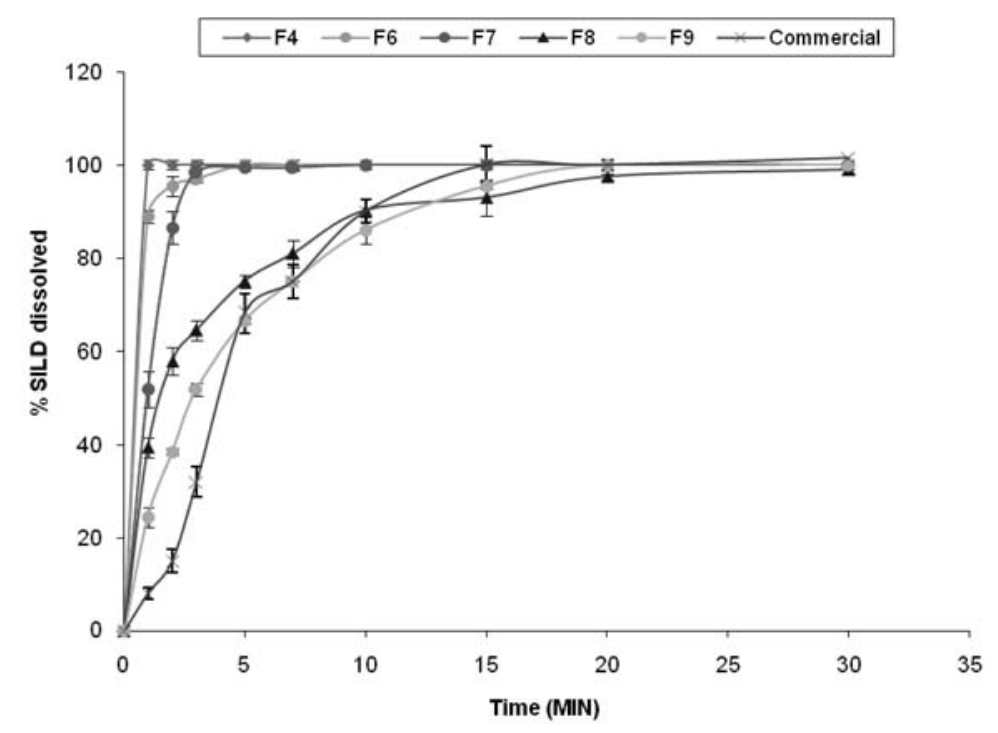

Fig. 5. Dissolution profiles of SILD lyophilized sublingual tablets in $500 \mathrm{~mL}$ distilled water.

tion. Tablets prepared by this technique have usually a light mass, with a very high specific surface area and a very porous open matrix network into which saliva rapidly moves to disintegrate lyophilized mass after it is placed in the mouth (29-30).

Overall results showed that F4 was the best formula; hence it was subjected to further in vivo studies to be compared with the S7 compressed tablet.

\section{PHARMACOKINETIC STUDY IN HEALTHY VOLUNTEERS}

Revatio ${ }^{\circledR}$ is absorbed after oral administration, with a mean absolute bioavailability of $41 \%$. The $T_{\max }$ ranges from 30 to 120 minutes (median60 min) from oral dosing in the fasted state.A high-fat meal delays the absorption of sildenafil citrate (7-8), with a mean delay in $T_{\max }$ of $60 \mathrm{~min}$ and a mean reduction in $C_{\max }$ of $29 \%$. Sildenafil and its major circulating $N$-desmethyl metabolite are both approximately $96 \%$ bound to plasma proteins. Protein binding is independent of total drug concentrations (31).

The mean plasma concentration versus time curves of SILD following administration of SD sublingual tablets (S7), lyophylized sublingual tablets (F4) and the commercial oral tablets (Revatio ${ }^{\circledR}$ ) to human volunteers are shown in Fig. 6. The corresponding mean pharmacokinetic parameters calculated from the individual curves are collectively summarized in Table VI.

The plasma concentration-time profiles as well as the calculated pharmacokinetic parameters showed that the prepared sublingual tablets improved the oral absorption of SILD, expressed by the significantly higher $C_{\max }(1.5-2$ fold $)$, significantly shorter $T_{\max }$ 
R. Zayed et al.: An in vitro and in vivo comparative study of directly compressed solid dispersions and freeze dried sildenafil citrate sublingual tablets for management of pulmonary arterial hypertension, Acta Pharm. 62 (2012) 411-432.

Table VI. Pharmacokinetic parameters of SILD after administration of SD sublingual tablets, lyophilized sublingual tablets and commercial oral tablets (Revatio $\left.{ }^{\circledR}\right)$ to human volunteers

\begin{tabular}{lccc}
\hline Pharmacokinetic parameter & $\mathrm{F} 4$ & $\mathrm{~S} 7$ & Revatio $^{\circledR}$ \\
\hline$C_{\max }\left(\mathrm{ng} \mathrm{mL} \mathrm{m}^{-1}\right)$ & $220.6 \pm 44.7$ & $187.2 \pm 63.5$ & $123.8 \pm 39.9$ \\
$T_{\max }(\mathrm{h})$ & $0.5 \pm 0.0$ & $0.75 \pm 0.0$ & $0.91 \pm 0.12$ \\
$A U C_{0-12}\left(\mathrm{ng} \mathrm{mL}^{-1} \mathrm{~h}^{-1}\right)$ & $603.3 \pm 93.0$ & $531.7 \pm 144.6$ & $377.5 \pm 132.6$ \\
$\mathrm{Lz}\left(\mathrm{h}^{-1}\right)$ & $0.11 \pm 0.03$ & $0.20 \pm 0.04$ & $0.17 \pm 0.08$ \\
$t_{1 / 2}(\mathrm{~h})$ & $6.96 \pm 2.94$ & $3.58 \pm 0.75$ & $4.99 \pm 2.84$ \\
Relative bioavailability (\%) & 159.81 & 140.85 & - \\
\hline
\end{tabular}

$\mathrm{C}_{\max }\left(\mathrm{ng} \mathrm{mL} \mathrm{m}^{-1}\right)$ : (Commercial), (F4, S7).

$T_{\max }(\mathrm{h})$ : (Commercial), (F4), (S7).

$\operatorname{AUC}_{(0-12)}\left(\mathrm{ngmL}^{-1} \mathrm{~h}^{-1}\right)$ : (Commercial), (F4), (S7).

$t_{1 / 2}(\mathrm{~h})$ : (Commercial, F4, S7).

* All formulae within the same brackets are not significantly different from each other but differ significantly from those in other brackets $(p<0.05)$.

and the significantly higher $A U C_{0-12}$ (nearly 1.5 fold) $(p<0.05)$ compared to the conventional oral tablet. The improved rate and extent of absorption and hence bioavailability of SILD might be due to the rapid disintegration and fast dissolution of sublingual tab-

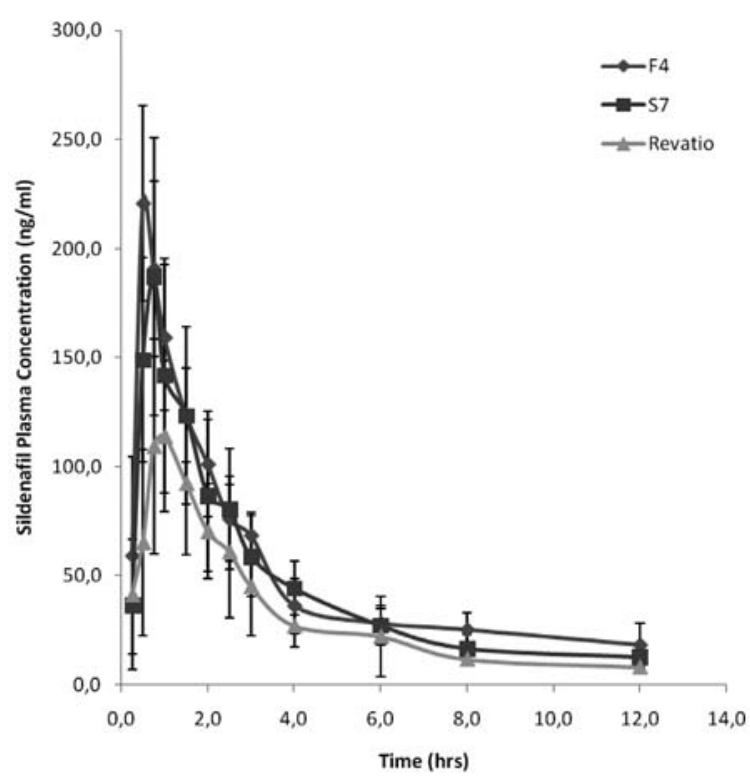

Fig. 6. Mean plasma concentration-time profiles of SILD after sublingual administration of F4, S7 and oral administration of the commercial product to human volunteers. 
lets with no variation in $T_{\max }(32)$. Moreover, the rapid transport of SILD across a single epithelial layer of the sublingual mucosa into the interstitial fluid on the basolateral side of the epithelial cells and then into the venous circulation might be the reason for the observed shorter $T_{\max }(30,33)$.

It is worthy to note that the method of sublingual tablet preparation had a significant effect on the bioavailability of SILD, as evidenced by the significantly shorter $T_{\max }$ of lyophilized tablets (F4) compared to directly compressed tablets (S7), with values of 0.5 and $0.75 \mathrm{~h}$, respectively. Moreover, the $A U C_{0-12}$ of lyophilized tablets (F4) was significantly higher than that of the directly compressed tablets, with relative bioavailability values of 159.81 and $140.85 \%$, respectively. This may be attributed to the fact that the freeze-drying process imparts a glossy amorphous structure to the bulking agent and sometimes to the drug, with an increase in the surface area and hence the surface free energy, resulting in an increase in the dissolution rate and therebybioavailability (34).

\section{CONCLUSIONS}

This comparative study reveals that both direct compression of SD and freezedrying were successful techniques in preparing SILDODSTs with significantly higher $C_{\max }$, significantly higher $A U C_{0-12}$, enhanced bioavailability and a rapid onset of action for treatment of acute attacks of PAH compared to the conventional oral product. Although freeze-dried sublingual tablets showed enhanced dissolution and bioavailability compared to directly compressed SD tablets, the SD technique by the fusion method is advantageous because it is less time consuming and economically less expensive in both processing and equipment.

\section{REFERENCES}

1. C. W. Oakley, Primary pulmonary hypertension. Case series from the United Kingdom, Chest. 105 (1994) 29S-32S; DOI: 10.1378/chest.105.2_Supplement.29S.

2. B. G. Schwartz, L. A. Levine, G. Comstock, V. J. Stecher and R. A. Kloner, Cardiac uses of Phosphodiesterase-5 Inhibitors, JACC 59 (2012) 9-15; DOI:10.1016/j.jacc.2011.07.051.

3. G. D. Lewis, R. Shah, K. Shahzad, J. M. Camuso, P. P. Pappagianopoulos, J. Hung, A. Tawakol, R. E. Gerszten, D. M. Systrom, K. D. Bloch, M. J. Semigran, Sildenafil improves exercise capacity and quality of life in patients with systolic heart failure and secondary pulmonary hypertension, Circulation 116 (2007) 1555-1562; DOI: 10.1161/ CIRCULATIONAHA.107.716373.

4. V. Q. Chau, F. N. Salloum, N. N. Hoke, A. Abbate and R. C. Kukreja, Mitigation of the progression of heart failure with sildenafil involves inhibition of RhoA/Rho-kinase pathway, Am. J. Physiol. Heart Circ. Physiol. 300 (2011) H2272-H2279; DOI: 10.1152/ajpheart.00654.2010.

5. J. Nagendran, S. L. Archer, D. Soliman, V. Gurtu, R. Moudgil, A. Haromy, C. St Aubin, L. Webster, I. M. Rebeyka, D. B. Ross, P. E. Light, J. R. Dyck, E. D. Michelakis, Phosphodiesterase type 5 is highly expressed in the hypertrophied human right ventricle, and acute inhibition of phosphodiesterase type 5 improves contractility, Circulation 116 (2007) 238-248; DOI: 10.1161/CIRCULATIONAHA.106.655266. 
6. L. Zhao, N. A. Mason, N. W. Morrell, B. Kojonazarov, A. Sadykov, A. Maripov, M. M. Mirrakhimov, A. Aldashev and M. R. Wilkins, Sildenafil inhibits hypoxia-induced pulmonary hypertension, Circulation 104 (2001) 424-428; DOI: 10.1161/hc2901.093117.

7. P. Rajagopalan, A. Mazzu, C. Xia, R. Dawkins and P. Sundaresan, Effect of high-fat breakfast and moderate-fat evening meal on pharmacokinetics of vardenafil, an oral phosphodiesterase-5 inhibitor for the treatment of erectile dysfunction, J. Clin. Pharmacol. 43 (2003) 260-267; DOI: $10.1177 / 0091270002250604$.

8. A. H. Elshafeey, E. R. Bendasand O. H. Mohamed, Intranasal microemulsion of sildenafil citrate: in vitro evaluation and invivo pharmacokinetic study in rabbits, AAPSPharmSciTech. 10 (2009) 361-367; DOI: $10.1208 /$ s12249-009-9213-6.

9. A. H. Shajaei, Buccal mucosa as a route for systemic drug delivery. J. Pharm. Pharmaceut. Sci. 1 (1998) 15-30; http://www.ualberta.ca/čcsps/JPPS1(1)/A.Shojaei/buccalreview.htm.

10. Z. Bayrak, C. Tas, U. Tasdemir, H. Erol, C. K. Ozkan, A. Sayaser and Y. Ozkan, Formulation of zolmitriptan sublingual tablets prepared by direct compression with different polymers: In vitro and in vivo evaluation, Eur. J.Parm. Biopharm. 78 (2011) 499-505; DOI: 10.1016/j.ejpb.2011.02.014.

11. S. A. Randale, C. S. Dabhi, A. R. Tekade, V. S. Belgamwar, S. G. Gattani and S. J. Surana, Rapidly disintegrating tablets containing taste masked metoclopramide hydrochloride prepared by extrusion-precipitation method, Chem.Pharm. Bull, 58 (2010) 443-448; DOI: 10.1248/cpb.58.443.

12. S. Bandari, R. K. Mittapalli, R.Gannu and Y. H. Rao, Orodispersibletablets: an overview, Asian J. Pharm. 2 (2008) 2-11; DOI: 10.4103/0973-8398.41557.

13. G. Abdelbary, C. Eouani, P. Prinderre, J. Joachim, J. Reynier and P. Piccerelle, Determination of the in vitro disintegration profile of rapidly disintegrating tablets and correlation with oral disintegration, Int. J. Pharm. 292 (2005) 29-41; DOI:10.1016/j.ijpharm.2004.08.019.

14. J. W. Moore and H. H. Flanner, Mathematical comparison of dissolution profiles, Pharmaceutical Technology, 20 (1996) 64-74.

15. »Declaration of Helsinki.« As amended by the 59th World Medical Assembly (WMA). World Medical Association, Seoul, South Korea, October 2008. Available at: http://www.wma.net/e/ ethicsunit/helsinki.htm.

16. V. P. Shah, K. K. Midha, S. Dighe, I. J. McGilveray, J. P. Skelly, A. Yacobi, T. Layloff, C. T. Viswanathan, C. E. Cook and R. D. McDowall, Analytical methods validation: bioavailability, bioequivalence and pharmacokinetic studies. Conference report, Eur. J. Drug Metab. Pharmacokinet. 16 (1991) 249-255; DOI: 10.1002/jps.2600810324.

17. A. P. Simonelli, S. C. Mehta, W. I. Higuchi. Dissolution rates of high energy polyvinylpyrrolidone-sulfathiazole coprecipitates, J. Pharm. Sci. 58 (1969) 538-549; DOI: 10.1002/jps.2600580503.

18. O. I. Corrigan, Mechanisms of dissolution of fast release solid dispersions. Drug Dev. Ind. Pharm. 11 (1985) 697-724; DOI: 10.3109/03639048509056896.

19. M. Newa, K. H. Bhandari, D. X. Li, T. H. Kwon, J. A. Kim, B. K. Yoo, J. S. Woo, W. S. Lyoo, C. S. Yong, H. G. Choi, Preparation, characterization and in vivo evaluation of ibuprofen binary solid dispersions with Poloxamer 188, Int. J. Pharm. 343 (2007) 228-237; DOI: 10.1016/j.ijpharm.2007. 05.031 .

20. N. Passerini, M. L. Gonzalez-Rodriguez, C. Cavallari, L. Rodriguez and B. Albertini, Preparation and characterisation of ibuprofen-poloxamer 188 granules obtained by melt granulation, Eur. J. Pharm. Sci. 15 (2002) 71-78; DOI: 10.1016/S0928-0987(01)00210-X.

21. P. P. Shah and R. C. Mashru, Development and evaluation of artemether taste masked rapid disintegrating tablets with improved dissolution using solid dispersion technique. AAPS Pharm. Sci. Tech. 9 (2008) 494-500; DOI: 10.1208/s12249-008-9066-4.

22. S. Khan, H. Batchelor, P. Hanson, Y. Perrie and A. R. Mohammed, Physicochemical characterization, drug polymer dissolution and in vitro evaluation of phenacetin and phenylbutazone solid 
R. Zayed et al.: An in vitro and in vivo comparative study of directly compressed solid dispersions and freeze dried sildenafil citrate sublingual tablets for management of pulmonary arterial hypertension, Acta Pharm. 62 (2012) 411-432.

dispersions with polyethylene glycol 8000, J. Pharm. Sci. 100 (2011) 4281-4294; DOI: 10.1002/ jps. 22613.

23. A. Quadir and K. Kolter, A comparative study of current superdisintegrants, Pharma. Tech. Com. 2006.

24. R. Chandrasekhar, Z. Hassan, F. Alhusban, A. M. Smith and A. R. Mohammed, The role of formulation excipients in the development of lyophilized fast-disintegrating tablets, Eur. J.Parm. Biopharm.72 (2009) 119-129; DOI: 10.1016/j.ejpb.2008.11.011.

25. W. L. Chiou and S. Riegelman, Pharmaceutical application of solid dispersion system, J. Pharm. Sci. 60 (1971) 1281-1302; DOI: 10.1002/jps.2600600902.

26. R. A. Shoukri, I. S. Ahmed and R. N. Shamma, In vitro and in vivo evaluation of nimesulide lyophilized orally disintegrating tablets, Eur. J.Parm. Biopharm.73 (2009) 162-171; DOI: 10.1016/ j.ejpb.2009.04.005.

27. V. B. Djagny, Z. Wang and S. Xu, Gelatin: A valuable protein for food and pharmaceutical industries: Review, Crit. Rev. Food Sci. Nutr.41 (2001) 481-492; DOI: 10.1080/20014091091904.

28. P. J. Dawson and D. J. Hockley, Scanning electron microscopy of freeze-dried preparations: relationship of morphology to freeze-drying parameters, Develop. Biol.Standard. 74 (1991) 185-192.

29. D. J. van Drooge, W. L. J. Hinrichs and H. W. Frijlink, Incorporation of lipophilic drugs in sugar glasses by lyophilization using a mixture of water and tertiary butyl alcohol as solvent, J. Pharm. Sci.93 (2004) 713-725; DOI: 10.1002/jps.10590.

30. A. A. Mahmoud and S. Salah, Fast relief from migraine attacks using fast-disintegrating sublingual zolmitriptan tablets, Drug Dev. Ind. Pharm. (2011) 1-8; DOI:10.3109/03639045.2011.625949.

31. REVATIO - sildenafil citrate tablet, film coatedPfizer Labs http://dailymed.nlm.nih.gov/ dailymed/archives/fdaDrugInfo.cfmfiarchiveid=10206.

32. A. Abdelbary, A. H. Elshafeeyand G. Zidan, Comparative effects of different cellulosic-based directly compressed orodispersable tablets on oral bioavailability of famotidine, Carb. Polym. 77 (2009) 799-806; DOI:10.1016/j.carbpol.2009.02.030.

33. M. M. Rawas-Qalaji, F. E. Simons and K. J.Simons, Sublingual epinephrine tablets versus intramuscular injection of epinephrine: Dose equivalence for potential treatment of anaphylaxis, $J$. Allergy Clin. Immunol. 117 (2006) 398-403; DOI:10.1016/j.jaci.2005.12.1310.

34. G. V. Betageri and K. R. Makarla, Enhancement of dissolution of glyburide by solid dispersion and lyophilization techniques, Int. J. Pharm. 126 (1995) 155-160; DOI: 10.1016/0378-5173(95) 04114-1.

\section{$S A \check{Z} E T A K$}

\section{Komparativna in vitro i in vivo studija sublingvalnih tableta dobivenih izravnom kompresijom čvrstih disperzija i liofiliziranog citrata za terapiju plućne arterijske hipertenzije}

REHAM ZAYED, AMANY O. KAMEL, MARWA SHUKR i ABD EL-HAMID EL-SHAMY

U radu je opisan razvoj sublingvalnih tableta citrata (SILD) raspršivih u ustima (ODST) za terapiju plućne arterijske hipertenzije (PAH), sa svrhom povećanja raspada nakon peroralne primjene, povećanja oslobađanja i bioraspoloživosti. Primijenjena je metoda izravne kompresije čvrstih disperzija (SD) sildenafila i poloksamera 188 i liofilizacija, a u izradi su upotrjebljena različita pomoćna sredstva. Evaluirana su fizikokemijska svojstva te oslobađanje ljekovite tvari iz tableta. Osim toga, na dobrovoljcima je uspore- 
R. Zayed et al.: An in vitro and in vivo comparative study of directly compressed solid dispersions and freeze dried sildenafil citrate sublingual tablets for management of pulmonary arterial hypertension, Acta Pharm. 62 (2012) 411-432.

đivana bioraspoloživost sildenafila iz ODST-a i standardnih tableta za peroralnu primjenu. Uklapanje SD poloksamera 188 u sublingvalne tablete uz Pharmaburst i korištenje izravne kompresije povećalo je oslobađanje SILD-a tako da je nakon 7 minuta $100 \%$ lijeka bilo otopljeno. Međutim, liofilizacija se pokazala superiornom za povećanje oslobađanja jer se $100 \%$ SILD-a oslobodilo nakon samo jedne minute. Štoviše, in vivo studije su pokazale da je $A U C_{0-12}$ liofiliziranih tableta bila značajno veća nego iz tableta dobivenih izravnim komprimiranjem, uz vrijednosti za bioraspoloživost od 159,81, odnosno 140,85 \% $\mathrm{u}$ odnosu na komercijalno dostupne proizvode.

Ključne riječi: sildenafil, raspršive sublingvalne tablete, plućna arterijska hipertenzija, poloksamer 188, čvrste disperzije, izravna kompresija, liofilizacija

Department of Pharmaceutics, National Organization for Drug Control and Research, Cairo, Egypt

Department of Pharmaceutics and Industrial Pharmacy, Faculty of Pharmacy, Ain Shams University, Cairo, Egypt 